\title{
Analisis Penurunan Miskonsepsi Siswa Setelah Mengikuti Pembelajaran Kooperatif Tipe STAD Berbantuan Simulasi Komputer
}

\author{
Ufiq Faishol Ahlif*, Achmad Samsudin dan Endi Suhendi \\ e-mail: ufiqku@gmail.com \\ Prodi Pendidikan Fisika FPMIPA Universitas Pendidikan Indonesia \\ Jl. Dr. Setiabudhi 229 Bandung
}

\begin{abstract}
Abstrak - Penelitian ini dilatarbelakangi oleh adanya miskonsepsi pada materi dinamika gerak melingkar. Penelitian ini bertujuan untuk menganalisis miskonsepsi siswa pada materi dinamika gerak melingkar. Penelitian dilakukan dengan metode quasi experiment menerapkan desain pre-test post-test control group design. Dalam penelitian ini dipilih subjek penelitian sebanyak 66 siswa yang terbagi ke dalam dua kelas, yaitu kelas eksperimen 33 siswa dan kelas kontrol 33 siswa. Data dikumpulkan menggunakan instrumen three tier test sebanyak 13 soal. Teknik analisis yang digunakan adalah uji hipotesis menggunakan uji Mann Whitney. Hasil penelitian menunjukkan bahwa mikonsepsi yang dialami siswa kelas eksperimen mengalami penurunan $6,77 \%$ setelah diberikan pembelajaran kooperatif tipe STAD berbantuan simulasi komputer. Sedangkan miskonsepsi siswa kelas kontrol mengalami penurunan sebesar 2,57\% setelah pembelajaran kooperatif tipe STAD tanpa simulasi komputer. Hasil uji hipotesis menunjukkan bahwa pada taraf signifikansi 5\%, penurunan miskonsepsi yang disebabkan pembelajaran kooperatif tipe STAD berbantuan simulasi komputer lebih signifikan dibandingkan penurunan miskonsepsi akibat pembelajaran kooperatif tipe STAD tanpa simulasi komputer.
\end{abstract}

Kata Kunci: miskonsepsi, pembelajaran kooperatif tipe STAD, simulasi komputer

\section{PENDAHULUAN}

Fisika merupakan ilmu yang dikembangkan dari temuan-temuan fenomena alam. Namun, fisika seringkali dianggap sebagai pelajaran yang sulit [1]. Salah satu kesulitan utama yang dihadapi siswa dalam proses pembelajaran fisika adalah adanya miskonsepsi dalam diri siswa [2].

Miskonsepsi adalah penafsiran konsep oleh seseorang yang tidak sesuai dengan penafsiran konsep oleh para ahli [3]. Penafsiran konsep dapat dilakukan oleh setiap orang ketika bersinggungan langsung dengan fenomena alam. Setiap orang akan mempunyai penafsiran konsep yang berbeda-beda atas satu fenomena yang sama. Interaksi dengan lingkungan akan memunculkan konsepsi (pemahaman konsep) awal dalam benak siswa. Konsepsi awal siswa berpotensi besar mengalami miskonsepsi. Artinya, penafsiran konsep fisika oleh siswa tidak sesuai dengan konsep fisika yang dikemukakan oleh ilmuwan.

Oleh karena miskonsepsi ini dapat berdampak buruk terhadap kualitas pemahaman siswa, perlu diidentifikasi faktorfaktor penyebab miskonsepsi itu sendiri. Banyak sekali faktor yang menyebabkan siswa mengalami miskonsepsi. Faktor-faktor penyebab miskonsepsi berasal dari metode pembelajaran, buku teks, miskonsepsi pada diri guru, dan pengalaman keseharian siswa.
Berdasarkan penelitian yang dilakukan oleh Saehana dan Kasim [4] telah terbukti bahwa simulasi komputer dapat mengurangi miskonsepsi. Hasil penelitian lain yang dilakukan oleh Mosik dan Maulana [3] bahwa strategi pembelajaran yang menekankan kepada keterlibatan siswa dalam membangun pemahamannya sendiri cukup efektif digunakan untuk mengurangi miskonsepsi. Untuk itu, penelitian dilakukan dengan memadukan simulasi komputer dengan pembelajaran kooperatif tipe STAD. Hasil yang ingin dilihat adalah penurunan miskonsepsi siswa.

Tujuan penelitian ini adalah mengetahui efektivitas penerapan simulasi komputer pada pembelajaran kooperatif tipe STAD dalam mengurangi miskonsepsi pada materi dinamika gerak melingkar.

\section{METODE PENELITIAN}

Penelitian ini dilakukan di salah satu SMAN di Kota Bandung. Populasinya adalah seluruh siswa kelas $X$ yang berjumlah 252 siswa yang terbagi ke dalam tujuh kelas dan masingmasing kelas terdiri dari 36 siswa. Sampel dalam penelitian ini adalah siswa kelas X MIA 7 sebagai kelas eksperimen dan siswa kelas $X$ MIA 5 sebagai kelas kontrol.

Metode penelitian quasi experiment digunakan dalam penelitian ini untuk mencari efektivitas penerapan simulasi komputer dalam mengurangi miskonsepsi. Pada kelas 
eksperimen dilakukan pembelajaran kooperatif tipe STAD dengan menerapkan simulasi komputer dan kelas kontrol diberikan pembelajaran kooperatif tipe STAD tanpa simulasi komputer. Sebelum dilakukan pembelajaran, siswa diberikan pre-test untuk mengetahui miskonsepsi awal siswa. Setelah dilakukan pembelajaran, siswa diberikan posttest untuk mengetahui penurunan miskonsepsi siswa.

Metode pengumpulan data dilakukan menggunakan instrumen tes miskonsepsi yang berbentuk three tier test. Instrumen tes miskonsepsi digunakan untuk mengukur miskonsepsi siswa yang terjadi sebelum dan sesudah pembelajaran.

Analisis data hasil pre-test dan post-test dilakukan untuk mengetahui efektivitas penurunan miskonsepsi. Analisis juga dilakukan dengan menguji hipotesis menggunakan uji Mann Whitney.

\section{HASIL DAN PEMBAHASAN}

Data yang diperoleh dari hasil pre-test dan post-test menunjukkan gambaran miskonsepsi yang dialami siswa sebelum dan sesudah diberikan pembelajaran. Data hasil pre-test dan post-test menunjukkan penurunan miskonsepsi pada kelas eksperimen dan kelas kontrol. Namun, penurunan yang terjadi pada kedua kelas menunjukkan perbedaan angka. Berikut disajikan data penurunan miskonsepsi pada materi dinamika gerak melingkar:

Tabel 1. Persentase miskonsepsi siswa

\begin{tabular}{|l|c|c|}
\hline & $\begin{array}{c}\text { Kelas } \\
\text { Eksperimen }\end{array}$ & $\begin{array}{c}\text { Kelas } \\
\text { Kontrol }\end{array}$ \\
\hline Pre-test & $14,93 \%$ & $23,08 \%$ \\
\hline Post-test & $8,16 \%$ & $20,51 \%$ \\
\hline Penurunan & $\mathbf{6 , 7 7 \%}$ & $\mathbf{2 , 5 7 \%}$ \\
\hline
\end{tabular}

Selanjutnya dilakukan penghitungan terhadap penurunan miskonsepsi dan efektivitas penurunan miskonsepsi yang diakibatkan oleh penerapan simulasi komputer pada pembelajaran kooperatif tipe STAD. Efektivitas penurunan miskonsepsi yang diakibatkan oleh penerapan simulasi komputer dapat diketahui dengan menguji hipotesis dan melakukan uji lanjutan metode Tukey. Uji hipotesis dilakukan berdasarkan data hasil post-test menggunakan uji Mann Whitney. Perhitungan uji hipotesis menggunakan uji Mann Whitney menghasilkan z hitung sebesar 4,28 . Sedangkan nilai $z$ tabel pada signifikansi $5 \%$ dan $\mathrm{dk}=32$ adalah 1,96. Berdasarkan hasil penghitungan uji Mann Whitney, diperoleh z hitung lebih besar dari pada z tabel, sehingga hipotesis nol $\left(\mathrm{H}_{0}\right)$ ditolak dan hipotesis alternatif (Ha) diterima. Hipotesis yang telah dirumuskan peneliti adalah:

$\mathrm{H}_{0}=$ Tidak terdapat perbedaan yang signifikan antara penerapan simulasi komputer pada pembelajaran kooperatif STAD dengan pembelajaran kooperatif STAD tanpa simulasi komputer dalam mengurangi miskonsepsi siswa.

$\mathrm{Ha}=$ Terdapat perbedaan yang signifikan antara penerapan simulasi komputer pada pembelajaran kooperatif STAD dengan pembelajaran kooperatif STAD tanpa simulasi komputer dalam mengurangi miskonsepsi siswa.

Dengan demikian, dapat disimpulkan bahwa terdapat perbedaan penurunan miskonsepsi yang signifikan akibat penerapan simulasi komputer pada pembelajaran kooperatif tipe STAD.

\section{Pembahasan}

Data hasil pre-test menunjukkan derajat miskonsepsi kelas eksperimen dan kelas kontrol sebelum diberikan pembelajaran. Penurunan miskonsepsi siswa dapat diukur dengan menghitung miskonsepsi sebelum pembelajaran dan sesudah pembelajaran. Penurunan miskonsepsi yang ditunjukkan siswa setelah pembelajaran kooperatif STAD berbantuan simulasi komputer lebih efektif dibandingkan siswa yang belajar tanpa simulasi komputer. Siswa yang dihadapkan pada fenomenafenomena yang membuat gagasan awal mereka terancam, akan lebih terbantu dengan keberadaan simulasi komputer. Keberadaan simulasi komputer dirasakan siswa dapat membantu dalam menganalisa konsep-konsep fisika. Senada dengan penelitian Saehana dan Kasim [4] bahwa media simulasi komputer dapat membantu siswa untuk mengurangi miskonsepsi. Hal ini dikarenakan siswa dapat melihat dan menganalisa konsep melalui simulasi komputer yang menjadikan konsepsi fisika siswa diperbaiki.

Menurut Ausubel [5], konsep dapat diperoleh siswa dengan dua cara, yaitu formasi konsep (concept formation) dan asimilasi konsep (concept assimilation). Formasi konsep dapat dilakukan siswa sebelum memperoleh pembelajaran di kelas. Formasi konsep terjadi akibat interaksi siswa dengan lingkungan. Pengamatan dan pembuktian terhadap gejala alam akan mempengaruhi struktur pemahaman siswa. Hasil formasi konsep yang sesuai dengan konsep yang dikembangkan ahli akan membantu proses pemahaman konsep selanjutnya yang lebih rumit. Namun, formasi 
ISSN 23383240

konsep yang salah menyebabkan siswa mengalami miskonsepsi. Dengan adanya miskonsepsi, siswa akan mengalami hambatan dalam menyusun struktur pengetahuannya terhadap konsep yang lebih kompleks.

Perlu adanya asimilasi konsep selama proses pembelajaran di kelas yang membantu siswa menyusun kembali konsep yang telah tertanam dalam benak siswa. Dalam proses asimilasi konsep, siswa diberikan konsep, abstraksi, dan atribut-atribut konsep. Dengan demikian, diharapkan siswa dapat menghubungkan informasi yang baru diterima dengan atribut konsep yang relevan dan sudah disusun dalam struktur pemahaman siswa.

Penurunan miskonsepsi memang dapat dilakukan dengan pembelajaran student centered. Salah satu model pembelajaran student centered adalah pembelajaran kooperatif tipe STAD. Namun, pembelajaran kooperatif tipe STAD saja kurang begitu efektif dalam menurunkan miskonsepsi siswa. Sehingga perlu adanya bantuan simulasi komputer dalam pembelajaran kooperatif STAD. Penggunaan simulasi komputer sebagai media pembelajaran mempunyai beberapa keuntungan, Kemp dan Dayton [6] yaitu:

1. Simulasi komputer dapat mengakomodasi siswa yang lamban dalam menerima pelajaran.

2. Simulasi komputer dapat mencakup kegiatan laboratorium yang sifatnya susah dilaksanakan karena keterbatasan alat dan keamanan.

3. Kendali media ada di tangan siswa, sehingga siswa bisa memanfaatkannya sesuai tingkat pemahamannya.

4. Proses pembelajaran menjadi lebih menarik.

5. Proses pembelajaran dapat dilakukan kapan dan dimana saja asalkan terdapat perangkat komputer.

Hasil penelitian juga menunjukkan adanya perbedaan penurunan miskonsepsi yang signifikan antara kelas eksperimen yang diberikan simulasi komputer pada pembelajaran kooperatif STAD dibandingkan dengan kelas kontrol yang diberikan pembelajaran kooperatif STAD tanpa simulasi komputer.

\section{KESIMPULAN}

Berdasarkan hasil penelitian yang telah dilakukan dapat disimpulkan bahwa penerapan pembelajaran kooperatif tipe STAD dapat mengurangi miskonsepsi siswa. Pembelajaran kooperatif tipe STAD berbantuan simulasi komputer menunjukkan penurunan miskonsepsi yang lebih efektif dibandingkan dengan pembelajaran kooperatif tipe STAD tanpa simulasi komputer. Dalam hal ini dapat dilihat pada taraf signifikansi $5 \%$, hipotesis yang menyatakan penurunan miskonsepsi kelas eksperimen lebih signifikan dari pada kelas kontrol diterima.

Penulis menyarankan agar guru lebih memperhatikan konsepsi awal siswa sebelum diberikan pembelajaran, menyesuaikan dengan hasil diagnosis miskonsepsi yang dialami siswa, dan mengajarkan konsep kepada siswa secara sistematis supaya dapat diterima dalam struktur kognitif siswa. Hasil penelitian ini dapat digunakan sebagai informasi dan pertimbangan dalam menggunakan metode dan media pembelajaran yang dapat mengurangi miskonsepsi siswa. Selain itu, berdasarkan penelitian ini, peneliti lain dapat menggunakan pendekatan pembelajaran yang berbeda.

\section{PUSTAKA RUJUKAN}

[1] Clement, J. (1981). Student's preconceptions in introductory mechanics. American Association of Physics Teacher, hlm.66-71.

[2] Tayubi, Y.R. (2005). Identifikasi Miskonsepsi Pada Konsep-Konsep Fisika Menggunakan Certainty of Response Index (CRI). Mimbar Pendidikan, hlm. 4-9.

[3] Mosik dan Maulana, P. (2010). Usaha Mengurangi Terjadinya Miskonsepsi Fisika Melalui Pembelajaran dengan Pendekatan Konflik Kognitif. Jurnal Pendidikan Fisika $6(-)$, hlm.98-103.

[4] Saehana dan Kasim. (2011). Studi Awal Miskonsepsi Mekanika Pada Guru Fisika SMA Di Kota Palu. Prosiding Seminar Nasional Penelitian, Pendidikan dan Penerapan MIPA Fakultas MIPA, Universitas Negeri Yogyakarta, 14 Mei 2011. Yogyakarta, hlm. 143-146.

[5] Novak, J.D. (2011). A Theory Of Education: Meaningful Learning Underlies The Constructive Integration of Thinking, Feeling, And Acting Leading To Empowerment For Commitment And Responsibility. Meaningful Learning Review, 1(2), hlm. 1-14

[6] Rahadi, A. (2003). Media Pembelajaran. DEPDIKNAS: Jakarta. 